\title{
Application of SFCL on Bus Tie for Parallel Operation of Power Main Transformers in a Fuel Cell Power Systems
}

\author{
Hui-Seok Chai*, Byoung-Wook Kang*, Jin-Seok Kim* and Jae-Chul Kim ${ }^{\dagger}$
}

\begin{abstract}
In the power plant using high temperature fuel cells such as Molten Carbonate Fuel Cell(MCFC), and Solid Oxide Fuel Cell(SOFC), the generated electric power per area of power generation facilities is much higher than any other renewable energy sources. - High temperature fuel cell systems are capable of operating at MW rated power output. - It also has a feature that is short for length of the line for connecting the interior of the generation facilities. In normal condition, these points are advantages for voltage drops or power losses. However, in abnormal condition such as fault occurrence in electrical system, the fault currents are increased, because of the small impedance of the short length of power cable. Commonly, to minimize the thermal-mechanical stresses on the stack and increase the systems reliability, we divided the power plant configuration to several banks for parallel operation. However, when a fault occurs in the parallel operation system of power main transformer, the fault currents might exceed the interruption capacity of protective devices. In fact, although the internal voltage level of the fuel cell power plant is the voltage level of distribution systems, we should install the circuit breakers for transmission systems due to fault current. To resolve these problems, the SFCL has been studied as one of the noticeable devices. Therefore, we analyzed the effect of application of the SFCL on bus tie in a fuel cell power plants system using PSCAD/EMTDC.
\end{abstract}

Keywords: DG interconnection, Parallel operation, Fuel cell, SFCL, Protection

\section{Introduction}

Recently, the development and dissemination of renewable energy have received much attention to deal with reduction of greenhouse gases and the depletion of fossil fuels. Renewable Portfolio Standard(RPS) which is a strategy that power producers supply a certain amount of renewable energy from their total power generation capacity has been in force since 2012 in South Korea and it is expected that the supply of renewable energy will be encouraged until 2022 by gradual increasing of supply obligation rate through RPS [1].

Even though the development and dissemination of solar and wind power generation have been actively worked on, it is not easy to secure the RPS's supply amounts of duty by solely using solar and wind power because it is very difficult to build a large scale power plant using the solar energy and it is greatly affected by the geographical location in case of wind power system. In addition, it is not easy to ensure stable power supply without auxiliaries such as Battery Energy Storage Systems(BESS) because of serious fluctuation in the power output.

The fuel cell system, however, can maintain constant power generation and its energy production per unit area is

\footnotetext{
$\dagger$ Corresponding Author: Dept. of Electrical Engineering, Soongsil University, Korea.(jckim@ssu.ac.kr)

* Dept. of Electrical Engineering, Soongsil University, Korea. (\{selaff, kangbw, redwolf832\}@ssu.ac.kr)

Received: November 24, 2014; Accepted: September 7, 2015
}

much higher than the wind or solar power systems. Thus, fuel cell power generation system could be a reasonable solution due to simplicity of capacity expansion and relatively few restrictions about power capacity only if fuel supply is guaranteed $[2,3]$. However, high temperature fuel cell operated in over $600^{\circ} \mathrm{C}$ is difficult to control or change the output power and also it takes a lot of time for startup or cooldown. Mostly, its change causes degradation of fuel cell life cycle so the fuel cell power generation system is required reasonable protection coordination systems [2].

Fuel cell generator of each that is made of dozens of fuel cells composing the scores of MW class's power complex will operate with a supply of the fault current in the event of fault of the internal organization and short power lines making up the internal organization will make equivalent impedance very small in condition of malfunction. Accordingly, a large fault current will be flowing fault point so that it must be required to install a large breaking capacity of circuit breaker. If the power plant builds additional facilities in response to increase of load, however, breaking capacity of the breaker will reach the limit.

According to increase of power generation equipment's capacity, it should be required at least two of MTR's parallel operation as well as capacity enhancement of them in order to improve reliability and efficiency of the power plant. The parallel operations of MTR offer have some merits in terms of cost and area of installation. However, there is a demerit that the large fault currents could be 
flowed in condition of internal fault because of small equivalent impedance. So the efforts to decrease the scale of fault currents have continued [7]. Superconducting Fault Current Limiter(SFCL) also has been the focus as an alternative to decrease fault currents, prevent power losses and voltage drop and maintain the safety of loss power system.

In this paper, we apply the Resistive Type SFCL(R-type SFCL) in bus tie in MCFC power plant and analyze fault current from three-phase short-circuit fault using PSCAD/ EMTDC. Thus, we aim to decrease breaking capacity by reducing fault currents and provide proper resistance value for preventing trip of trouble-free fuel cell for preserving the fuel cell life degradation.

\section{Configuration and Modeling of the Large Scale Fuel Cell Power Plant}

Hwaseong, Kyengki Province in South Korea, there has been managing a fuel cell power plant of $58.8 \mathrm{MW}$ class $(\mathrm{K}$ fuel cell plant) connected two main transformers(MTR) with 21 modules of MCFC [6]. As shown on Fig. 1, K-fuel cell plant is equipped with a structure coupled with interconnection transformer by combining fuel cell power generator with buses. These lines, transformers, and buses connected with grid are made with dual for the system reliability.

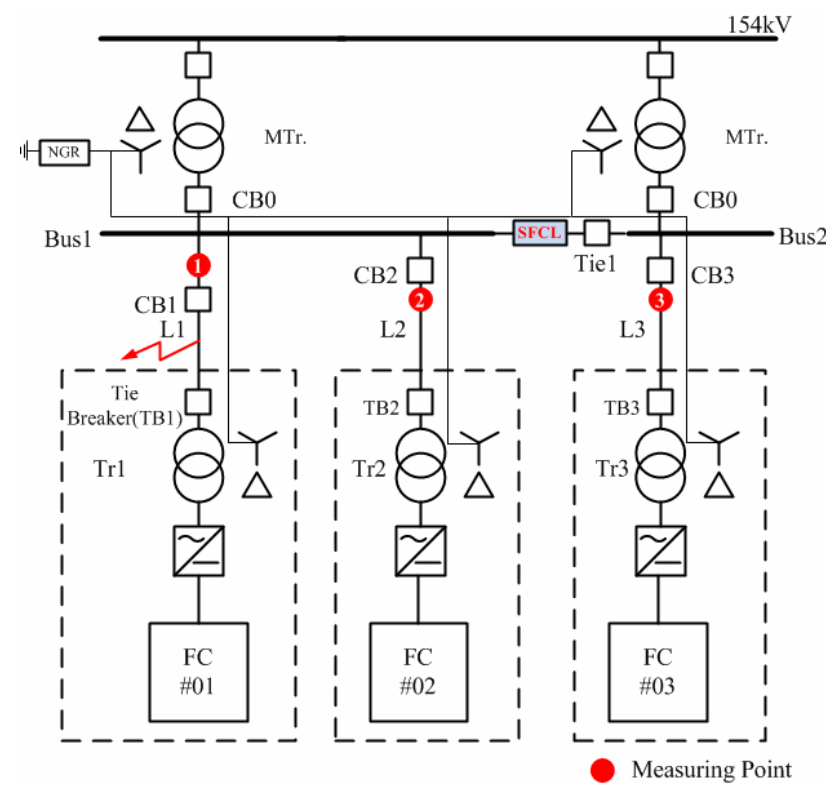

Fig. 1. Fuel cell generation system configuration, Korea

\subsection{Molten Carbonate Fuel Cell(MCFC)}

High temperature fuel cell such as Molten Carbonate Fuel Cell(MCFC) or Solid Oxide Fuel Cell(SOFC) can use carbon monoxide as well as hydrogen as a fuel and exhausted heat energy has advantage of being considered having possibility to draw out high efficiency through combined cycle installed extra power generation process [2]. MCFC can compose renewable energy power plant of mass capacity consisted of multiple MCFC equipment because equipment of $2.8 \mathrm{MW}$ has already been introduced into market [3]. However, high temperature fuel cell operated in over $600^{\circ} \mathrm{C}$ is difficult to control or change the output power because of thermal-mechanical stress and also it takes a lot of time for startup or cooldown. Because of this long time for cooldown, when the faults occur in electrical system, MCFC cannot reduce the electric power immediately. Mostly, its change causes degradation of fuel cell life cycle so the fuel cell power generation system is required reasonable protection coordination systems [2]. Another problem is the very small short circuit impedance. In the power plant using MCFC, the generated electric power per area of power generation facilities is much higher than any other renewable energy sources. - High temperature fuel cell systems are capable of operating at MW rated power output. - It also has a feature that is short line or cable for connecting the interior of the generation facilities. In abnormal condition such as fault occurrence in electrical system, the fault currents are increased, because of the small impedance of the short length of power cable. To supplement these weakness, high temperature fuel cell manufacturers provide independent technology controlling temporary output by adjusting inflow of fuel $[4,5]$.

Fig. 2 shows internal structure of each of the MCFC modules. A number of fuel cell stacks are connected with step-up transformer through inverter and the transformers' 3rd winding supply the electric power to Balance Of Plant (BOP) of the fuel cell module. The above BOP equipment includes pump for fuel, air, and heat recovery, air blower, and water purification equipment and so on.

The circuit breaker is installed in connecting point between the power generation system and a step-up transformer for system separation $[2,3]$.

The protection elements are generally presented in the

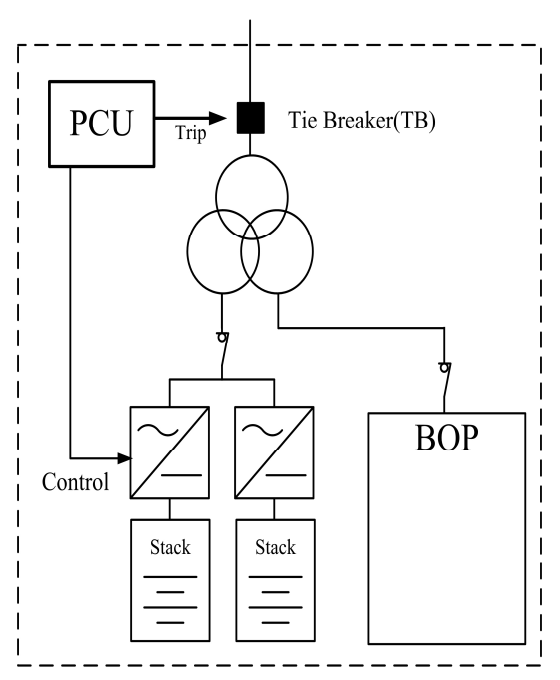

Fig. 2. Inside structure of fuel cell plant 
Table 1. Protective relay function of fuel cell generation system

\begin{tabular}{c|l}
\hline ANSI Number & \multicolumn{1}{c}{ Protective relay function } \\
\hline 25 & Synchronizing relay \\
\hline $59 / 27$ & Over/Under voltage relay \\
\hline $81 \mathrm{OI} / \mathrm{U}$ & Over/Under frequency relay \\
\hline $50,50 \mathrm{G}$ & Instantaneous phase/ground overcurrent relay \\
\hline $51 \mathrm{G}$ & Time ground overcurrent relay \\
\hline
\end{tabular}

IEEE Std. 1547, are summarized in Table 1 [8]. These elements are implemented through Power Conditioning Unit(PCU). When the external fault detection, PCU open the Tie Breaker(TB). At this moment, the fuel cell module will operate in the island operation mode as it supplies electric power only to BOP during fault duration. After the external grid returns and is seen to be stable, the fuel cell module is designed to automatically synchronize and connect to the utility grid.

In this paper, we define that the external fault is the electrical fault at the power generation system. In fact, the voltage level of the fuel cell power plant is the voltage level of distribution systems. When an external fault occurs in the power system, the fault current will flow in the power system until the fault removed. At this time, if we install the circuit breaker for distribution systems, the fault currents might exceed the interruption capacity of protective devices. As a result, although the internal voltage level of the fuel cell power plant is the voltage level of distribution systems, we should install the circuit breakers for transmission systems due to fault current. However, the circuit breakers for transmission systems are extremely more expensive than the circuit breakers for distribution systems. In order to construction of an economical power plant and safe and efficient operation, we should reduce the fault current using the SFCL.

\subsection{Resistive-type SFCL modeling}

In order to limit fault currents, many models for the SFCL have been developed such as resistive-type, reactivetype, trigger-type, and so on. [10]. In this paper, we modeled a resistive-type SFCL that is mostly basic and used widely which represents the experimental studies for superconducting elements of SFCL. Quench and recovery characteristics of a resistive-type SFCL are modeled based on [10] and [11]. A resistance of the SFCL according to time $t$ is given as follows:

$$
R(t)=\left\{\begin{array}{lr}
0 & \left(t<t_{0}\right) \\
R_{n}\left[1-\exp \left(-\frac{t-t_{0}}{T_{F}}\right)\right]^{\frac{1}{2}} & \left(t_{0} \leq t<t_{1}\right) \\
a_{1}\left(t-t_{1}\right)+b_{1} & \left(t_{1} \leq t<t_{2}\right) \\
a_{2}\left(t-t_{2}\right)+b_{2} & \left(t \geq t_{2}\right)
\end{array}\right.
$$

Table 2. Parameters of modeled SFCL

\begin{tabular}{c|c|c|c|c|c|c}
\hline Parameter & $R_{n}[\Omega]$ & $T_{F}[\mathrm{~s}]$ & $a_{1}$ & $a_{2}$ & $b_{1}$ & $b_{2}$ \\
\hline Value & 5 & 0.01 & -40 & -120 & 5 & 3 \\
\hline
\end{tabular}

where, $R_{n}$ and $T_{F}$ are the resistance saturated normal temperature and time constant. In addition, $t_{0}, t_{1}$, and $t_{2}$ are the quench-starting time, first recovery-starting time, and secondary recovery-starting time, respectively. $a_{1}, a_{2}, b_{1}$, and $b_{2}$ are coefficients of the first-order linear function to denote the experimental results of the recovery characteristics of the SFCL [10-12]. The values used for the parameters are summarized in Table 2.

\subsection{Three phase ungrounded fault study}

To analyze the fault current due to external fault of the 58.8MW fuel cell power plant, the parameters of impedance and capacity for fuel cell power plant are summarized in Table 3. The rated output current of the fuel cell module is 131A. When the fault occurs, we assume the output current of the inverter has the limit to $110 \%$ of the rated current due to the PCU control. If the current is over than the limit, fuel cell module will trip. The contribution of the fault current from the inverter is small. So, we ignored fault current contribution of the inverter [9].

Fig. 3 shows the fuel cell power plant model as shown in Fig. 1 using PSCAD/EMTDC. The three-phase ungrounded fault occurs in the line connecting between the bus and transformer FC1. We summarized the parameters of a fuel

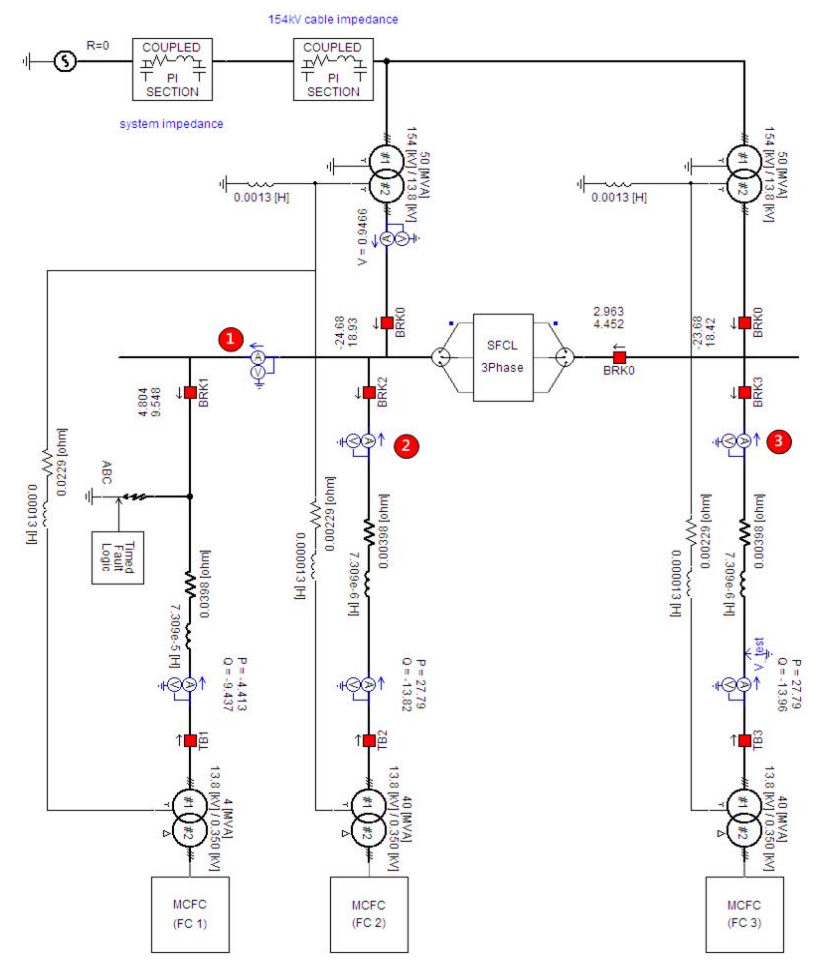

Fig. 3. Fuel cell generation system model by PSCAD/ EMTDC 
Table 3. Impedance and capacity of MCFC fuel cell generation system

\begin{tabular}{c|c|c}
\hline & Capacity \& Impedance & remarks \\
\hline $\begin{array}{c}\text { Grid side } \\
\text { impedance }\end{array}$ & $\begin{array}{c}\mathrm{Z} 0=0.585+\mathrm{j} 2.860 \% \\
\mathrm{Z} 1=0.151+\mathrm{j} 1.561 \%\end{array}$ & $\begin{array}{c}100 \mathrm{MVA}, \\
154 \mathrm{kV}\end{array}$ \\
\hline MTr. & $\begin{array}{l}154 \mathrm{kV} / 13.8 \mathrm{kV} \\
50 \mathrm{MVA}, \mathrm{j} 13 \%\end{array}$ & Self capacity \\
\hline Cable impedance & $\begin{array}{c}\mathrm{Z} 0=20.62+\mathrm{j} 14.56 \% / \mathrm{km} \\
\mathrm{Z} 1=12.97+\mathrm{j} 5.73 \% / \mathrm{km}\end{array}$ & $\begin{array}{c}100 \mathrm{MVA}, \\
13.8 \mathrm{kV}\end{array}$ \\
\hline Cable length & $110 \mathrm{~m}$ & $1 \mathrm{EA}$ \\
\hline Tr 1 in FC 1 & $\begin{array}{c}0.35 \mathrm{kV} / 13.8 \mathrm{kV} \\
4 \mathrm{MVA}, \mathrm{j} 3.19 \%\end{array}$ & $10 \mathrm{EA}$ \\
\hline Tr 2 in FC 2 & $\begin{array}{c}0.35 \mathrm{kV} / 13.8 \mathrm{kV} \\
4 \mathrm{MVA}, \mathrm{j} 3.19 \%\end{array}$ & $1 \mathrm{EA}$ \\
\hline Tr 3 in FC 3 & $2.8 \mathrm{MW}$ & $10 \mathrm{EA}$ \\
\hline MCFC (FC 1) & $\begin{array}{c}2.8 \mathrm{MW} \\
\text { MCFC(FC 2, FC 3) }\end{array}$ & \multicolumn{2}{|c}{$5 \Omega$} \\
\hline Fault Type & \multicolumn{2}{|c}{ Three phase ungrounded fault } \\
\hline SFCL impedance & \multicolumn{2}{|c}{}
\end{tabular}

cell power plant for modeling of PSCAD / EMTDC in Table 3.

\section{The Effect of the Resistive-Type SFCL}

We proposed the application of SFCL in fuel cell power plant system as the ways that is to decrease the fault current capacity through the equipment and the way of preserving the lifespan of fuel cells. Also, we checked the current flowing into the fault point at the measuring-point 1 , 2 , and 3 in case of three-phase ungrounded fault at the fault point as seen in Fig. 1.

Fig. 4 are deducted coming results by simulation that if SFCL is applied to fault current flowing into the fault point from grid side and an adjacent fuel cell or not. Before the fault occurrence at $0.5 \mathrm{~s}$, the load current is $131 \mathrm{~A}_{\mathrm{rms}}$ in the normal state. In case of uninstalled SFCL shown in Fig. 4(a), we should install a circuit breaker with a rated breaking capacity of $40 \mathrm{kA}$ in order to block the current safely which is $28.7 \mathrm{kA}$ and flowing into fault point [13]. But if we could install the SFCL shown in Fig. 4(b), it is possible to reduce the fault current by $19.3 \mathrm{kA}$ and enables to replace breaking capacity of circuit breaker from $40 \mathrm{kA}$ to $25 \mathrm{kA}$. Also, it means that it is possible to increase the power generation capacity more that at present when using a breaker with $40 \mathrm{kA}$.

Fig. 5 shows results of simulations that one is fault current of adjacent fuel cell(FC2) connected to the fuel cell with fault(FC1) and the other one is the fault current in the fuel cell(FC3) connected with bus(Bus 2, at measuring point 3) in parallel mode. The fault current at FC 2 is increased when the SFCL is applied, however, the fault current at FC 3 is decreased. This phenomenon is simply explained shown in Fig. 6. If the SFCL is not applied, because of the similar length of power line or cable, each FC circuit's equivalent impedances are similar shown in Fig. 6(a). However, when the SFCL is applied, the
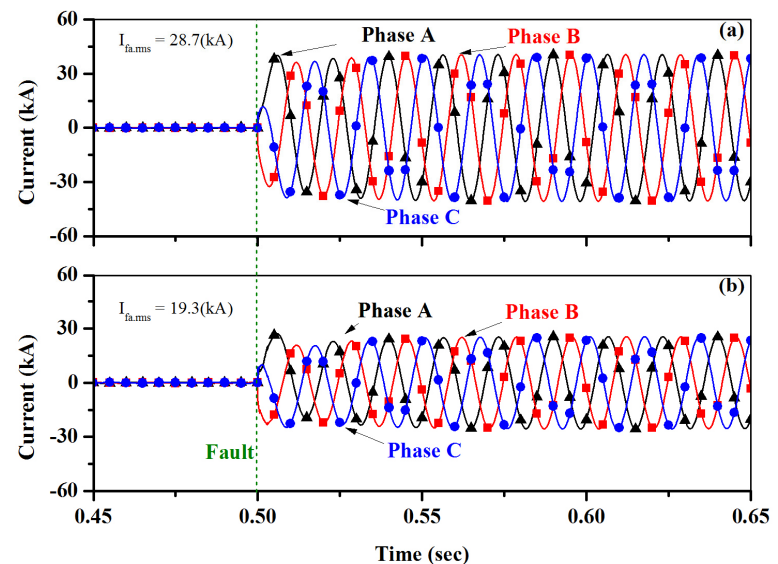

Fig. 4. Fault currents at measuring point 1: (a) without SFCL; (b) with SFCL
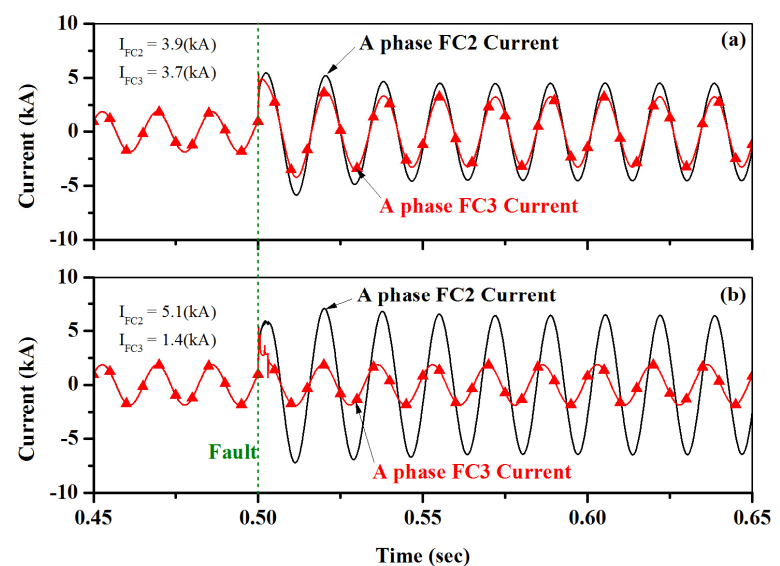

Fig. 5. Fault currents at measuring point 2, and 3: (a) without SFCL; (b) with SFCL

equivalent impedance for the opposite side of fault point due to additional SFCL's impedance has change shown in Fig. 6(b). Following the current division formula, each FC fault current has change.

Fig. 5(a) shows fault current in case of without SFCL. In this case, each fault currents flowing through FC2, and $\mathrm{FC} 3$ are $3.9 \mathrm{kA}$ and $3.7 \mathrm{kA}$. It means that this current flows with $370 \mathrm{~A}$ in condition of single module. If the SFCL is not installed, all fuel cells will experience trip and their lifespan will be shortened regardless of where the internal fault occurs. However, in Fig. 5(b) shows that fault current flowing from FC2 is $5.1 \mathrm{kA}$ when the SFCL is applied. It represents $510 \mathrm{~A}$ of fault current flows in single module condition. That is why all fuel cells connected with Bus1 can experience trips. On the other hand, the fault current from FC3 is reduced to $1.4 \mathrm{kA}$ by the resistance of the SFCL. It means that current would be flow with $140 \mathrm{~A}$ in single module condition and the fuel cell connected to Bus2 without trip could be operated because the fault current does not exceed the limit value of the inverter.

Therefore, it is possible to preserve lifespan of the fuel cell connected to the Bus2. 


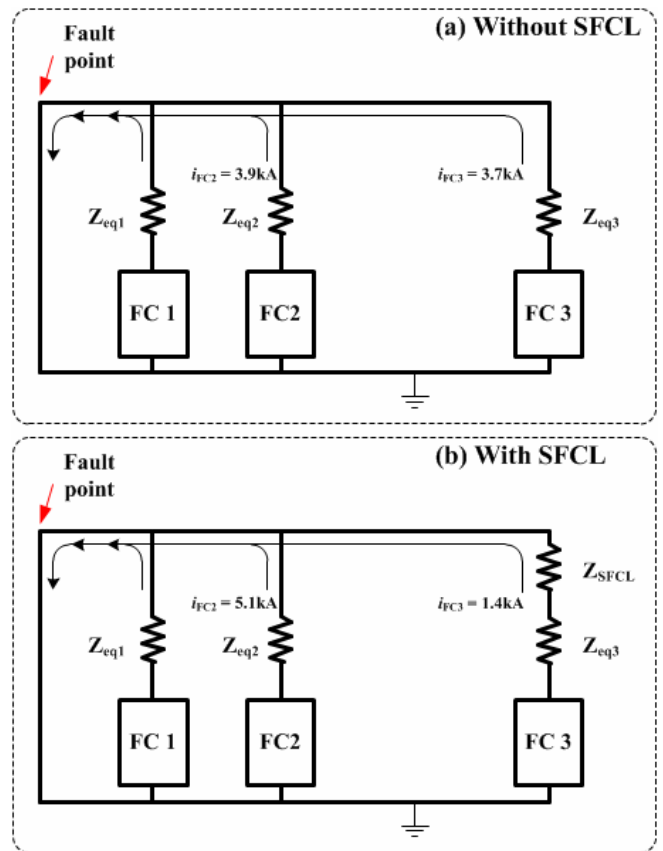

Fig. 6. Simplified equivalent circuits according to fault cases

\section{Conclusion}

The fuel cell system is one of renewable energy sources which are able to generate power constantly. The fuel cell system has a lot of advantages. However, fuel cell systems tend to have high fault currents because it comparably features small equivalent impedance and high power density. And the fluctuation of output power causes degradation of fuel cell life cycle. To resolve these problems, we propose the application of SFCL.

In this paper, we modeled the K-Fuel cell power plant in South Korea using PSCAD/EMTDC. We applied the SFCL in bus tie in K-fuel cell power plant and simulated the three-phase ungrounded fault. We confirmed the decreased breaking capacity of circuit breaker by reducing fault currents.

Application of SFCL is able to reduce the fault current $28.7 \mathrm{kA}$ to $19.3 \mathrm{kA}$. If the fuel cell system is in design stage, we can reduce the required breaking capacity of circuit breaker. Also if the fuel cell system is in operational stage, we are able to increase the generation capacity using fuel cell or other resources.

Also we confirmed the possibility from preventing trip of trouble-free fuel cell for preserving the fuel cell life degradation by SFCL. When the SFCL is applied, the fault current of fuel cell modules connected the opposite bus is $140 \mathrm{~A}$ for single module. It is $107 \%$ of rated current. Through this result, fuel cell life can be preserved.

As a result, the SFCL is able to a reasonable alternative for the efficiency improvement of fuel cell power plant and preservation of the life cycle of fuel cell stack by preventing trip.

\section{Acknowledgements}

This work was supported by Human Resources Development of the Korea Institute of Energy Technology Evaluation and Planning (KETEP) funded by the Ministry of Trade, Industry and Energy under Grant 2013 4010200570 .

\section{References}

[1] Ministry of Knowledge Economy, "Renewable Portfolio Standard Management and Operation Guidelines", March, 2013.

[2] G. S. Nam, "Hydrogen Fuelcell Handbook", Sungandang, 2011.

[3] FuelCell Energy, Inc., "DFC 3000 Specifications"

[4] R. Venkataraman, and W. Liyingood, "Method and System for Recovering High Power Output Operation of High Temperature Fuel Cells by Using Rapid Load Recovery Procedure", European Patent EP 2050161 B1, 2012.

[5] H. M. Yoon, S. Y. Jung, D. H. Kim, and B. K. Lee, "Dynamic Analysis MCFC for Mass Power Generation System", Power Electronics Annual Conference, pp. 254-256, 2010.

[6] K. Y. Kim, S. H. Ji, M. S. Lee, B. M. Kim, D. S. Rho, Y. M. Oh, M. K. Kang, "The Analysis of Operation Characteristic in Large Scale Fuel Cell System", The Conference on KIEE, pp. 503-504, July, 16-18, 2014.

[7] M. G. On, M. H. Kim, J. S. Kim, I. K. You, S. H. Lim, and J. C. Kim, "A Study on the Application of SFCL on $22.9 \mathrm{kV}$ Bus Tie for Parallel Operation of Power Main Transformers in a Power Distribution System", KIEE Trans., Vol. 60, No. 1, Jan., 2011.

[8] IEEE Std. 1547, "IEEE Standard for Interconnecting Distributed Resources with Electric Power Systems", 2003.

[9] Y. H. Chong, H. S. Chai, J. C. Kim, and S. M. Cho, "A Study on the Operation Condition by Electrical Fault in the High Temperature Fuel Cell Plant", KIIEE Trans., Vol. 27, No. 8, Aug. 2013.

[10] S. H. Chang, K. H Oh, and J. H. Kim, "Analysis of voltage unbalance in the electric railway system using two-port network model", KIEE Trans., Vol. 50A, pp. 248-254, May, 2001.

[11] J. S. Kim, S. H. Lim, and J. F. Moon, et al., "Analysis on the protective coordination on neutral line of main transformer in power distribution substation with superconducting fault current limiter", KIEE Trans., Vol. 58, pp. 2089-2094, Nov., 2009.

[12] H. R. Kim, S. W. Yim, and O. B. Hyun et al., "Analysis on recovery characteristics of supercon- 
ducting fault current limiters", presented at the Conference on Magnet Technology, Philadelphia, Aug. 27-31, 2007, MT-20.

[13] J. C. Kim, "Electrical Technology for On-site Practice", Kidari, 2001.

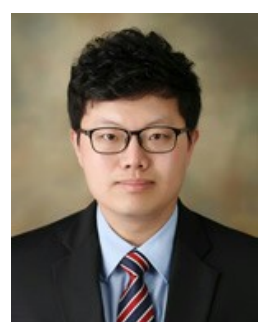

Hui Seok Chai He received his B.S. degree in electrical engineering from Soongsil University, Korea, in 2011, respectively. Currently, he is student of Soongsil University graduate school integrative course. His research fields of interest include distribution power system, distribution system reliability, diagnosis, and fuel cell power plant.

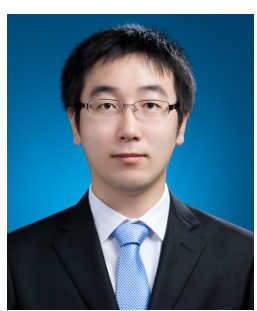

Byoung Wook Kang He received his B.S., M.S. degree in electrical engineering from Soongsil University, Korea, in 2010 and 2012, respectively. Currently, he is student of Soongsil University graduate school doctoral course. His research fields of interest include electric railway, distributed generation inter connection, and power quality.

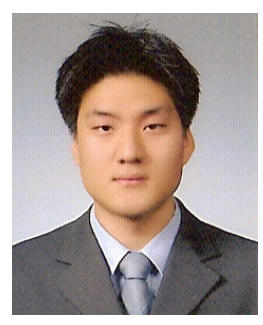

Jin-Seok Kim He received his B.S. degree from Electrical Engineering at Seoul National Univ. of Science and Technology in 2007 and his M.S., Ph.D. degree from Electrical Engineering at Soongsil Univ. in 2009 and 2014, respectively. Currently, he is a professor in the Dept. of Electrical Engineering at Soongsil Univ. Korea.

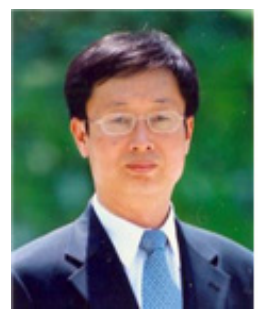

Kim, Jae-Chul He received his B.S. degree from Electrical Engineering at Soongsil Univ. in 1979 and his M.S. and Ph.D. degrees from Seoul National Univ. in 1983 and 1987, respectively. Currently, he is a professor in the Dept. of Electrical Engineering at Soongsil Univ. Korea. 